\title{
On the hegemonic power of the pandemic discourse
}

\author{
Richard J. Alexander \\ Emeritus Professor \\ Vienna University of Economics and Business Administration
}

Austria

\section{ABSTRACT}

The paper claims that corona discourse is here to stay. The pandemic has achieved hegemony over humanity. The everyday discourse patterns that from the start were packed with medical and epidemiological terms and phrases have come to stay. And epidemiology has become in no uncertain terms the new hegemony. What has happened brings to mind Gramsci's idea of hegemony which captures and imprisons us. One section looks at how the UK government dealt with the pandemic. Some aspects have been underplayed by the government from the start of the pandemic. One is how COVID-19 has affected certain socio-economic groups and professions differently. What the majority of the media comments on COVID-19 and the measures being taken, such as the just quoted UK politicians and experts are involved in, lack is a bigger picture. Their attention is focused on immediate problems and proximate causes. The effects of the pandemic on people's lives are briefly analyzed. The rapid vaccine production and rollout have changed the situation.

At the same time, the emergence and rapid spread of new variants have demonstrated what global health experts warned all along: that none of us is safe until everyone is safe.

Subsequent sections discuss, firstly, the focus on molecular biology and the neglect of the broader eco-social frame within which such viruses develop. Secondly, the failure to prepare for the current pandemic is alluded to. A significant issue concerning the role of the European Union and the pharmaceutical companies like AstraZeneca in the delivery of vaccines is discussed. Attempts and actions to counteract the hegemonic control are outlined.

The discussion of the situation of COVID-19 within the broader context of environmental disintegration rounds off the paper.

\section{Keywords: pandemic, COVID, discourse, health, vaccine, government}

\section{Introduction}

The author has returned to a project first addressed last year namely how the hegemonic medicalized corona discourse which had been identified and analyzed is persisting and controlling the language of the political elites and the world in general. This is especially the case in Europe and of course for the avoidable catastrophe of the British government's handling of the pandemic. This discourse is continuing to dominate the media wavelengths and radio and TV stations and newspapers and other media and we will be attempting to make sense of this in critical discourse analytical terms.

The corona discourse is here to stay. The pandemic has achieved hegemony over humanity. As Alexander (2020) stated: "The hegemonic power of the pandemic has made us all party to this new hegemony." Accordingly, the discourse it has brought forth now practically rules in most orders of discourse. Certainly, the political order and government edicts are now subservient to and party to the language of infection, illness, death, and vaccination.

The corona discourse has become a fixture in our lives. In radio and TV programs and the newspaper media, everybody is caught up in the epidemiological jargon. Especially now with the prospect of vaccinations becoming available, the talk has shifted to how societies can adjust somehow to returning to a more open economy while still maintaining stringent COVID-19 hygienic conditions in shops https://ijbassnet.com/ and public life while wearing masks and keeping social distance, in many countries now, at two meters. Even as vaccinations proceed, more rapidly and efficiently in some countries than in others, governments are advising a precautionary approach.

The chaos of shortage of vaccines in Austria, where the author lives, and in the EU as a whole show that the uncertainty that accompanies everything in our personal and social situations is something we must live with.

Science and scientists' discourse has become more prominent in the media as the pandemic endures. Disputes between scientists and the interpretation of 'evidence' have become visible. There are however no certainties involved in scientific research; what we learn is always provisional. For the layperson, the sight of two or more scientists interpreting the evidence about, say different strains or variants of the COVID-19 virus, in different ways, can give the impression that disputes and not definitive claims are the stuff of scientific activity. Given the mysteries that viruses present to scientists, it is always a case of assessing probabilities.

The medical doctor Phil Whitaker (2021) puts this into perspective: "It is a hallmark of the scientific method that all theories are provisional, subject to challenge and revision as new data emerges. The UK was blindsided by the first wave: our pandemic plan, geared wholly towards an influenza virus, proved fatally flawed, with an early abandonment of http://dx.doi.org/10.33642/ijbass.v7n6p3 
E-ISSN: 2469-6501

VOL: 7, ISSUE: 6

June/2021

http://dx.doi.org/10.33642/ijbass.v7n6p3

CPER

\section{(C) Center for Promoting Education and Research (CPER) USA}

www.cpernet.org

containment, and a shift instead merely to try to keep infection rates within health service capacity."

People expect "clarity in uncertain times. Such a general claim needs some interpretation. What are we talking or thinking about? If the phrase is used as a journalistic advertising slogan I caught it being used on SkyNews it may mean nothing more than that we can expect good reporting on world events or something like that.

But expecting clarity and certainty in science is another matter. Consider how people are likely to react when medical and scientific experts usually university professors of global health or epidemiologists or virologists are asked to comment on the efficacy of a vaccine. When one report states that AstraZeneca's vaccine does not appear to be as effective as expected against the South African variant of the virus and that the South African government is stopping using it, what are we supposed to think when some experts on the media state quite unambiguously that they think the vaccine is still effective in preventing death and serious illness?

The lockdowns currently in effect in most European countries in January 2021, as the 'second wave' now with the new variants and strains from Britain and South Africa which are extremely transmissible, look set to persist in some cases perhaps until Easter-4 April- according to the reports from Germany at any rate.
The lockdowns that continue are affecting most societies in different ways. As observers, we are making a sustained effort to understand how people are talking about the COVID-19 pandemic.

\section{The hegemonic control of the medicalized language and discourse}

The everyday discourse patterns that from the start were packed with medical and epidemiological terms and phrases have come to stay. And epidemiology has become in no uncertain terms the new hegemony. These everyday discourse patterns informed and peppered by medical and epidemiological terms and phrases are now everywhere on social media, on the radio on TV programs, and in the newspapers.

This discourse is now an integral part of the daily language of politicians and governments everywhere. The pandemic is a public health issue that most governments in the world have taken on board as the priority. Saving lives is the reason given for the lockdowns, for example in European countries, where the second (or third) wave of high infection rates are the leading event. The focus is very individualcentered. Stay at home and save lives is the message. These photographs in the UK illustrate the ubiquitous nature of this situation.

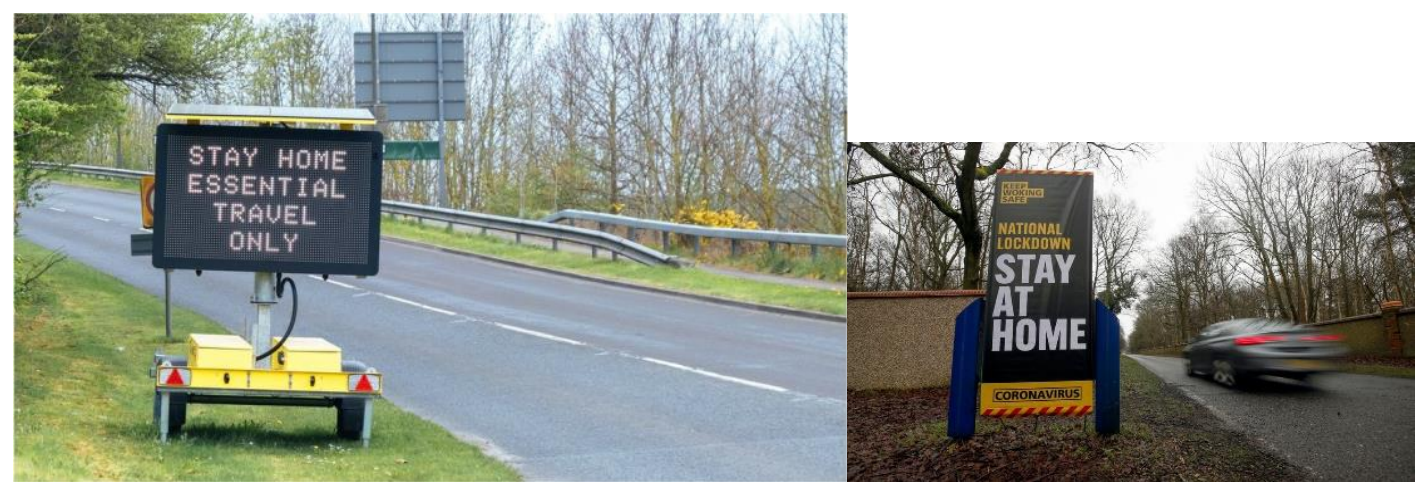

What has happened brings to mind Gramsci's idea of coerced into accepting the measures and the behavior the hegemony (1971: 12-13). This hegemonic control captures and lockdowns have given rise to. imprisons us (people). Epidemiology and epidemiologists' jargon is a significant part of the new hegemony. Hegemony constitutes lived experience. It gives rise to a sense of reality for most people in the absolute society, because they experience a reality beyond which it is very difficult for most members of the society to move, in most areas of their lives.

We find a Gramscian hegemonic control at work in the medicalized language and discourse, which is operating, in the political order of discourse and the mainstream media, and the social media. This has resulted in populations being controlled in several European nations. In their role as citizens and voters, they were for the most part consenting to their domination by ruling governments; in other words, citizens have succumbed to their governments and they are not being simply forced or
This kind of hegemony, therefore, applies argumentative or educative pressure to single individuals to obtain their consent and their collaboration; in this way, necessity and coercion are translated into 'freedom'. "Social hegemony" names the 'spontaneous' consent given by the great masses of the population to the general direction imposed on social life by the dominant fundamental group which accompanied how citizens accepted social distancing and abided by government requirements. But in addition, there was the apparatus of state coercive power that 'legally' enforced discipline on those groups who did not 'consent' either actively or passively.

As seen in the abstract we can thus say that the hegemony attempts to neutralize opposition. The decisive 


\section{(C) Center for Promoting Education and Research (CPER) USA}

www.cpernet.org

hegemonic function is to control or transform or even incorporate or co-opt any alternatives and opposition that might persist.

The hegemonic control that the pandemic discourse now holds over the whole of the world is still regulating both informally and formally (or legally) what life in many societies and countries is like. This now prevailing discourse has thrust a human-centric perspective onto practically everything.

\section{Our first focus: the UK government's dealing with the pandemic}

Almost a year on into the pandemic the journalist George Monbiot (2021) writes: "The UK is trapped in a cycle of lockdown and relaxation, without an exit strategy".

When he asked the UK government what the plan was, his comment on the answer he received highlighted the language: "All it could offer was a paragraph of waffle from the prime minister's latest press conference, in which he appeared to suggest that he might relax some measures when the most vulnerable groups have been vaccinated." Most TV viewers and citizens in the UK have become inured to the prime minister's 'waffle'.

More than 1,000 people in the UK died of COVID-19 on average each day in January 2021, making it the deadliest month of the pandemic so far by the government's count, with more than 28,000 deaths up to 25 January 2021.

In the afternoon of 26 January, 2021 SkyNews announced that there were 1,631 deaths that day, bringing the total of deaths from COVID-19 to 100,162 total deaths in the UK. This is a 'sobering moment in the pandemic' said a medical director. The Sky anchorwoman discussed this with their deputy political editor and called it a 'shocking moment'.

The SkyNews journalists tempered the terrible news by talking about how the vaccination program is a positive moment with over 6 million people have received the jab. This evening there was to be a press conference in which Boris Johnson, the Prime Minister, intended to speak to the nation at this distressing time. The anchorwoman said it was a terrible milestone, with so many families grieving the loss of a family member ... and not just old people. They showed a clip of a 36-year old Asian woman's daughter recalling her mother's death. The anchorwoman said that the PM wanted to address the unimaginable grief the nation was experiencing. He wanted to help the collective grieving. She expected the tone to be interesting; he would want to stress the positive aspects and talk about the vaccine program.

Britain has now suffered over 100,000-recorded deaths from COVID-19, the highest toll in Europe and one of the highest per-capita death rates in the world. The intensity of the COVID-19 discourse and the manner, by which it is saturating society, so profoundly, that it appears like the new common sense, is sometimes difficult to capture as a discourse analyst. To be sure, we can note the way the epidemiological phraseology is being used by both the experts and the politicians; we see too how it has insinuated its way into how laypersons are being compelled to adjust their daily living patterns wearing surgical masks in some countries. (In Austria: 'All shoppers and visitors must wear FFP2 masks.')

We can respond to this by listing lexicalizations and the relative frequency of recurring new words in the vocabulary of the media in the UK. In January and February 2021 one of the most frequently used words by the UK government was 'vaccine'. A relatively new word in the vocabulary of the media, government, and experts was 'variant' or 'variants'. In his press conference on 25 January Matt Hancock, the Health Secretary had a lot to say about these. And when we look more closely at its use we find interesting collocational co-texts figuring in his statements: "The final thing I want to say is this, there is no question that the new variants have made this fight a whole lot tougher. And I want to set out again, precisely, what we know about the new variants. As with all science, as we have ... we're learning more all of the time, and the new variant that was first discovered in Kent, which comprises now a significant number of our cases, is spreading 30 to $70 \%$ more easily than the existing variants.

And based on analysis conducted by academic colleagues in a variety of studies, there is a realistic possibility that this variant may be associated with increased mortality compared to the old variant, as well as increased transmission. And because of our extensive genomic sequencing, we've identified cases of the new variant, first identified in South Africa, and that one that was first identified in Brazil. And further scientific work is underway to understand more about these variants. ... And alongside this new situation, we are all "learning"'

The Deputy Chief Medical Officer Dr. Harris, who shared the press conference with Matt Hancock, continued to use the term. "We are still learning a lot about this virus, about the new variants, and our body's response to it." "So this is still very much a learning landscape. ... As the Secretary of State has highlighted, there are particular measures in place, which certainly at the start of an understanding of a variant is important for us to be able to learn about its transmissibility and what the impact might be in the country." "We're learning more all of the time."

While we are using examples of medicalized discourse used at press conferences we can bring in the comments made by Professor Van-Tam, the deputy chief medical officer for England, on February 8, 2021. Professor Jonathan Van-Tam, a plain-speaking voice of calm authority in uncertain times, has become something of a household name and is a regular and reassuring associate at the once-daily government briefings. He attempts to transform complex science into language the layperson can better understand.

He was explaining why he did not believe the South African variant would become dominant in the UK. He 


\section{(C) Center for Promoting Education and Research (CPER) USA}

wwW.cpernet.org

claimed that the UK Kent variant accounted for more than $90 \%$ of cases in Britain and that there had been fewer than 200 cases of the South African strain. Here is an analogy he employed:

"If you are running a bath and you have got the hot water tap on and you add in a very small amount of cold water, so the cold tap is running as well but at really a very low volume, your bath water is going to remain hot," he said.
"It's only if that could tap was gushing much more than the hot tap, the cold water would take over.

"That's probably the best analogy I can give you at the moment. There are no signs that the South African variant is running at that speed at the moment and therefore I don't frame it as something that is going to be a dominant issue in the next few months."

\section{Collocational co-texts of 'variant'}

\begin{tabular}{l}
\hline the new variants have made this fight a whole lot tougher \\
\hline what we know about the new variants. \\
\hline the new variant that was first discovered in Kent, \\
\hline it is spreading 30 to $70 \%$ more easily than the existing variants. \\
this variant may be associated with increased mortality \\
compared to the old variant, as well as increased transmission. \\
And because of our extensive genomic sequencing, we've identified cases of the new variant, first identified in South Africa, \\
and that one that was first identified in Brazil. \\
\hline And further scientific work is underway to understand more about these variants \\
\hline We are still learning a lot about this virus, about the new variants, and our body's response to it. \\
there are particular measures in place, which certainly at the start of understanding of a variant is important for us to be able to \\
learn about its transmissibility and what the impact might be in the country."
\end{tabular}

We can highlight how politicians and ministers in government bright-side, or deliver good news first for instance with the advent of vaccinations on the scene and the rapid rollout in the UK while they simultaneously react to the daily death toll they have to announce.

On 25 January 2021 Matt Hancock reported proudly: "As of today, 6.6 million have now received a vaccine against COVID-19. That's more than one in nine of the adult population. On Saturday alone, we gave nearly half a million jabs. And in the last week, two and a half million people have been vaccinated across the UK. That's a rate of more than 250 people a minute. We're on track to offer everyone in the top four priority groups a jab by the 15th of February. And if you are in one of those groups, one of the top four priority groups, and you haven't had the call yet, don't worry. The NHS will be in touch."

Some aspects have been underplayed by the government from the start of the pandemic. As a University College London study found out in 2020, adjusting for age and region, the risk of death from COVID-19 for Black African groups was 3.24 times higher than the general population; the Black Caribbean was 2.21 times higher; Pakistani was 3.29 times higher; Bangladeshi was 2.41 times higher, and Indian was 1.7 times higher. In contrast, researchers found a lower risk of death from COVID-19 for white populations in England. After accounting for region and age, the risk of death for White Irish was half (0.52 times) that of the general population, and for White British was 12\% (0.88 times) lower.

Similar findings can be found in the United States, as a ScienceBlog from Princeton stated on January 21, 2021: "The COVID-19 pandemic's disproportionate effect on the life expectancy of Black and Latino Americans likely has to do with their greater exposure through their workplace or extended family contacts, in addition to receiving poorer health care, leading to more infections and worse outcomes."

In the case of Britain, studies suggest that the UK's fragmented society is to blame, as the huge disparities in the death toll between the rich and poor and across ethnic backgrounds highlight. Many have raised concerns over how the government's mixed messages have created confusion and ultimately may have contributed to the rapid spread of the virus, especially among poor and ethnic communities.

Boris Johnson has on many occasions during the pandemic said things to the population that was ambiguous and unclear, to say the least. Take this example in a TV address to the nation on 22 September 2020, announcing early closing for pubs:

"If we were forced into a new national lockdown, that would threaten not just jobs and livelihoods but the loving human contact on which we all depend ... We must do all we can to avoid going down that road again."

So clearly occupational exposures to COVID-19 by race and ethnicity need to be considered, as do social class 
origins or socio-economic factors. Such statistics and observations have led Kamran Abbasi (2021), the editor of the British Medical Journal, to evoke the term "social murder" in connection with COVID-19. He calls upon a historical parallel: "The philosopher Friedrich Engels coined the phrase when describing the political and social power held by the ruling elite over the working classes in 19th century England. He argued that the conditions created by privileged classes inevitably led to premature and "unnatural" death among the poorest classes."

He continues with a further literary reference: "In The Road to Wigan Pier, George Orwell echoed these themes in describing the life and living conditions of working-class people in England's industrial north. Today, "social murder" may describe the lack of political attention to social determinants and inequities that exacerbate the pandemic."

He tones down slightly his comments in legal terms when he writes: "If not murder or a crime against humanity, are we seeing involuntary manslaughter, misconduct in public office, or criminal negligence?" He expands: "but as more than two million people have died, we must not look on impotently as elected representatives around the world remain unaccountable and unrepentant."

And when we consider the cumulative fashion in which the COVID-19 fatalities have ramped up in certain areas of the world it is small wonder that many people are dissatisfied with their governments (Abbasi 2021): "From the United States to India, from the United Kingdom to Brazil, people feel vulnerable and betrayed by the failure of their leaders. The over 400,000 deaths from COVID-19 in the US, 250,000 in Brazil, 150,000 each in India and Mexico and 100,000 in the UK comprise half of the world's covid death toll - on the hands of only five nations."

So against this background, there is concurrently a clear need to acknowledge what is an existential facet to the impact the COVID-19 discourse is having on all of us, including any soberly analyzing scholars. As we said, the pandemic is a public health issue, which most governments in the world have taken on board as the priority. Saving lives is the reason given for the lockdowns, for example in European countries, where the second (or third) wave of high infection rates are the leading event. The focus is very individualcentered. Stay at home and save lives is the message.

Let us recall that there are so many people who have lost relatives and friends to the disease or who know personally individuals who have caught the disease and have or still are suffering from its effects, e.g. with 'long Covid'. We may know those who have mercifully recovered without any noticeable damage to their health. So what we have called 'an existential facet' will resonate far more in-depth than for those people hitherto untouched by the virus.

Then we must underline the fact that the hegemonic power of the ongoing COVID-19 discourse is after all a reflection of how humanity is responding to what is a continuing emergency with hitherto no predictable end in sight. As the evolutionary biologist and public health phylogeographer, Rob Wallace, caustically observes, (2020: 141) in the context of medical studies that misrepresent COVID-19's case fatality as not different from influenza and given the uncertainty about the effectiveness of vaccines and the lack of herd immunity, the pathogen 'could still exert considerable damage.' And, given his expert knowledge, he also asks a question emergency-fixated scientists and politicians choose to ignore: "Why not discuss the accelerating emergence of multiple spillover effects?" referencing Smith K.F. et al (2014). When it comes to risk analysis is it not preferable to seriously prepare for an outbreak rather than fail to prepare for a true danger? Why not err on the side of precaution?

This was not what the UK government did in March 2020, as Alexander (2020: 30) notes: "Countries had plans for how to deal with pandemics. But many governments appear to have ignored their existence or what they implied by way of making preparations. According to the UK 2011 plan, 50 percent of deaths were expected over three weeks."

What the majority of the media comments on COVID19 and the measures being taken, such as the just quoted UK politicians and experts are involved in, lack is a bigger picture. Their attention is focused on immediate problems and proximate causes. Wallace in his scathing portrait of the epidemiology profession (2020:27) captures this situation well: "Almost the entirety of the profession is presently organized around post-hoc duties, much like a stable boy with a shovel following behind the elephants at a circus. Under the neoliberal program, epidemiologists and public health units are funded to clean up the system's mess, while rationalizing even the worst practices that lead to many a deadly pandemic's emergences."

Faulkner (2021) underlines what is happening: "Covid is a human-made catastrophe, as much an artifact of the Anthropocene as global warming." And also he adds: "Mainstream commentary on the pandemic is refracted through a neoliberal prism."

Wallace (2020: 144) refers to the realities on the ground: "a pandemic strain that hopscotched from bat caves on the other side of the world into the lungs of urban workers in the USA".

Even though scientists are daily learning about COVID-19 and the virus SARS-CoV-2 that causes it, the research virologist of Queen's University, Belfast, Connor Bamford (2021), poses some important scientific questions looking to the future. "The first is how will SARS-CoV-2 evolve, adapt and change over the next year in the face of natural or acquired immunity through vaccination?" "Then there is the question of how SARS-CoV-2 will interact with the other viruses that circulate in humans. The human 
respiratory tract is home to several viruses that circulate together often in a single person. These viruses promote or impede the infection of other viruses."

We have just argued how there is a need for a bigger picture and Bamford in part addresses this issue with his third question: "Finally, we must identify the origin of SARS-CoV2 to prevent the continued spill-over of SARS-CoV-2-like (or indeed other pathogenic coronaviruses) into humans. We know that SARS-CoV-2 probably emerged recently in south-east Asia and that ultimately the virus was in a horseshoe bat. But the biological and ecological steps it took to reach humans remain obscure. Solving this puzzle will help safeguard our health for decades to come, in the same way as has been achieved for swine and avian flu infections."

\section{Effects of the pandemic on people's lives}

Death and the prospect of dying are in the air and affecting us all and most people's lives. Medical staff in hospitals and ambulance men and women are working under extremely stressful conditions to deal with very ill patients. In TV news programs hospital pictures reminiscent of what was shown in March and April in North Italian hospitals in 2020 were once more making the rounds in January 2021.

As Alexander (2020) stated: "In the face of such ubiquitous pandemic discourse it is not surprising that many people express feelings of helplessness and being inextricably caught up in structures too big for them."

At this point, we can bring in the sociological term 'anomie' that the French sociologist Émile Durkheim used to describe a social condition in which there is a disintegration of norms and high levels of uncertainty in society.

In his 1897 book, Le Suicide Durkheim identified this concept and noted that when things rapidly change in a society people often may not know how to behave or respond. This raises levels of stress, frustration, anxiety, and confusion. It can even prompt feelings of powerlessness.

An American social worker, Holly Dreger (n.d.), has commented on this phenomenon: "The routines of our daily lives have been disrupted, and in some cases, abandoned for something entirely different. Our sense of autonomy and ability to influence the outcome has also been restricted. Feelings of powerlessness have driven some to cope by hoarding supplies, buying up provisions to mitigate anxiety and fears about going without. We are a society that is waiting for the threat to pass.

"Experts in mental health are encouraging those who are physically distancing at home to keep a schedule, to step away from constant media consumption, to focus on "positives," and to embrace the time this crisis has created."

Psychologically, 'anomie' can make individuals feel on the verge of societal collapse. The changes in many people's lives during the past year of the pandemic have brought about anomic and socially disoriented circumstances.
Alexander Gelfand (2020) argues that the initial coronavirus surge has passed, but the mental health fallout persists. This can entail fear of infection, worry over sickened loved ones, and grief for those who have died. The measures adopted to stop the virus's spread, like social distancing, school closures, and work restrictions themselves can lead to loneliness, financial insecurity, and domestic violence. He quotes a mental health expert who notes that the duration of the crisis itself becomes a psychological stressor. He sees interesting parallels with comparable crises: "In terms of cumulative impact, that makes the COVID-19 pandemic more like the Great Depression or World War II than other recent infectious disease crises such as the 2009 swine flu pandemic or the 2015-16 Zika epidemic."

For example, there is evidence that primary school pupils in England have suffered "significant" learning loss during the lockdown and school closures. Disadvantaged pupils have been affected most by the pandemic and the disruption to their schooling in 2020. Source https://www.theguardian.com/commentisfree/2021/jan/29/teen age-mental-health-crisis-britain-schools-shutdown-youngpeople

A Cambridge University research group in the area of clinical neuropsychology under Professor Sahakian (2021) comments on how many opportunities for social learning for children have been foregone under COVID-19 lockdowns. They ask how this will affect children's development and what can be done about it. They note a study showing that people experienced a reduction in positive feelings making them biased to think negatively which was significantly related to how socially connected they were. Those who were less socially connected were more affected.

They comment: "It is likely that children are even more vulnerable when it comes to long-term effects of a delay or absence in peer-to-peer interaction. We know that social brain development is a two-way street the environment, in this case, social interaction between peers, affects the brain and the brain affects the emotional and behavioral response to peers."

They quote one mother, who had to cope with perpetual lockdowns, put the problem very clearly... "My sixyear-old suddenly gets very shy when talking to his classmates on Zoom". And she continues: "kids aren't just missing out on seeing their peers, grownup role models such as grandparents and teachers are suddenly gone too. Most young children I know don't like video calls, so it's not a substitute for social interaction the way it can be for adults."

Furthermore, in several countries over the past months the effects of the lockdowns on mental health, particularly among children and young people, are very much in evidence. Pandemic fatigue is starting to spike. There has been an increase in stress, anxiety levels, depressive symptoms, and sleep disturbances. In the UK, in one study, just over 3,000 adults were surveyed and a range of mental health factors was 


\section{(C) Center for Promoting Education and Research (CPER) USA}

www.cpernet.org

considered, including depression, loneliness, suicide attempts, and self-harm.

A spokesperson from the UK charity Mind says that the national mental health picture looks grim. "It's no understatement to say that the nation is facing a 'mental health pandemic'," she says. "It's clear that our mental health is deteriorating across the board from mild mental health problems right through to those reaching crisis point and even having to be hospitalized." This is a representative view from a young student during the lockdown: "I am worried that another lockdown will cause my anxiety to get worse and my mood to drop again."

At universities, academics are struggling to support students through the difficulties of the COVID-19 pandemic. Then on top of this many universities in the UK have announced plans for staff job cuts to save money.

In a Financial Times article Chris Allnutt (2021) reported on how the pandemic lockdown was affecting students at British universities: "In her first year at the University of Bristol, Saranya Thambirajah has had little contact time for her politics course but plenty of hands-on experience mobilizing protests and organizing direct action against the institution's pandemic response."

He shows how they are suffering financially: "Despite the impact of the pandemic on teaching, social life, and mental and physical health, students are having to fight for the most basic rent reductions to university-owned accommodation; the cheapest room offered by the university costs $£ 4,300$ a year in rent. And all the while they are paying more than $£ 9,000$ in tuition fees every year."

Elsewhere it is also an issue: "It is not just in England that students are up in arms. More than 50 US colleges, including George Washington University and NYU, face lawsuits from students seeking compensation for amenities closed during the pandemic. Last month, Paris's Left Bank saw a series of demonstrations drawing attention to poverty and declining mental health at universities. In Scotland, meanwhile, where education policy is handled by the devolved government, students in Glasgow protested against their treatment by erecting a fence around their vice-principal's lodgings."

\section{Vaccine production and rollout}

Given the fact that there are now vaccines available that have been developed, tested, and trialed in record time, the emphasis for governments is on supplying the vaccinations to firstly vulnerable patients and then in turn to as many patients as possible and as soon as possible to create herd immunity. This is likely to happen in a small number of countries like Israel and the United Kingdom,

What the British government calls the 'rollout' of the vaccines has become the good news that the Prime Minister, Boris Johnson, is keen to bring to the forefront of the discourse as he touches on the possible loosening of the lockdown. "And so it follows that if we're to get schools open and keep them open, which is what we all want, then we need to be clear about certain things. We need to be sure that the vaccine rollout is continuing to be successful, as it is. Most important, we need to see the impact of our vaccines on those graphs of mortality. We need to see that they are saving lives and preventing people from becoming seriously ill. Now, we're confident that that will happen, and the vaccines will have that effect, but to be responsible, we must see the proof, and our current estimates say that the proof will only become visible in the middle of February."

The longer-term problem is that the more the virus continues to spread in poorer countries, the more likely it is that a vaccine-resistant strain will emerge and threaten to undo the progress made by rich countries so far, The New Statesman wrote on $1 \mathrm{Feb} 2021$, citing sub-Saharan Africa as a particular worry.

So it is going to be vital how widely in the world, especially in the Global South, for example in Africa and South America, vaccinations can be supplied to underdeveloped countries with overstretched health systems. On the world stage, in addition to the unequal ecological exchange between the Global North and South, there now is the inequality in vaccine supply to be added to the equation. On 12 February 2021, there was a TV report on the situation in Mozambique that has a lot of cases of COVID-19 and no vaccines whatsoever. A doctor interviewed on the program estimates it will last at least 5 years before people will be vaccinated in the country. As of February 11, Mozambique has 47,790 confirmed COVID-19 cases and 501 deaths. A total of 30,124 individuals have recovered from the disease.

On September 7, 2020, Mozambique transitioned from a State of Emergency (SOE) to a State of Public Calamity (SOPC). The SOPC will continue indefinitely at the red alert level while the risk of spreading COVID-19 exists in Mozambique. Source https://mz.usembassy.gov/COVID-19information/

As The Guardian wrote: "The desire to look after one's own is understandable in both human and political terms. But to consign others to take their chances is inhumane and short-sighted. The head of the World Health Organization said recently that we were on the brink of a catastrophic moral failure, with younger, healthier adults in richer countries being vaccinated before health workers and older people in poorer ones. The emergence and rapid spread of new variants have demonstrated what global health experts warned all along: that none of us is safe until everyone is safe." Source https://www.theguardian.com/commentisfree/2021/jan/28/theguardian-view-on-vaccine-nationalism-think-again

\section{The focus on molecular biology and the neglect of the} broader eco-social frame

Virologists working on vaccines for COVID-19 operate in terms of biochemistry. They are working out the 


\section{(C) Center for Promoting Education and Research (CPER) USA}

www.cpernet.org

genomic properties of the virus. The proteins that make it are the focus. On the other hand, the microbial ecosystem of the biome is of no interest to the majority of such scientists.

The researchers' emphasis is on molecular biology and studying the genomic makeup with a view to the development of vaccines against COVID-19. We can bring in Rob Wallace at this point as he talks about the coronaviruses like SARS (severe acute respiratory syndrome) and MERS (Middle East Respiratory Syndrome) we have encountered over the years and their relative virulence (2020: 26): "It should change how we think about them. I would recommend we err on the side of viewing disease causality and intervention beyond the biomedical or even ecohealth object and out into the field of ecosocial relationships."

Wallace expands (2020: 26): "One source of vexation is the dimensionality of the problem. There is even among mainstream scholars dawning realization influenza is more than mere virion or infection; that it respects little of disciplinary boundaries (and business plans) in both their form and content. Pathogens regularly use processes accumulating at one level of biocultural organization to solve problems they face at other levels, including the molecular."

Earlier Wallace (2020: 22) neatly situates his remarks within the discourse frame we have elucidated above: "And, as my colleagues and I argue, emergency criteria are deployed as impositions in Gramscian hegemony to keep us from talking about structural interventions around power and production. Because don't you know, warned, IT'S AN EMERGENCY RIGHT NOW!"

The discourse of politicians is similarly nonecological. The relationships that arise between humans and more-than-human organisms are simply off their radar. And this has happened despite the evidence arising from a variety of scientific disciplines, as the professor of sociology, John Bellamy Foster (2020), notes:

"The sudden appearance of dangerous new zoonoses such as SARS, MERS, and H1N1 resulted over the last decade in the rise of the One Health approach to the etiology of disease, bringing together analyses from zoology, microbiology, epidemiology, ecology, veterinary medicine, and public health, aimed at developing a more systematic approach to epidemics.

"Through superior to earlier, reductionist approaches, and quickly adopted by the World Bank, the World Health Organization, and the Centers for Disease Control and Prevention in the United States, the dominant ideological basis of One Health meant that it backed off from a holistic approach in one very crucial respect: the consideration of capitalism, including the scrutiny of agribusiness and global commodity chains."

Hence the failure to prepare for the current pandemic need not surprise us. Wallace (2020: 45) makes the reasons for this clear: "The failures were programmed decades ago as the shared commons of public health were simultaneously neglected and monetized. A country captured by a regimen of individualized, just-in-time epidemiology - an utter contradiction - with barely enough hospital beds and equipment for normal operations, is by definition unable to marshal the resources necessary to pursue a China brand of suppression."

Wallace (2020: 46) underlines the limitations of modeling: "Models such as the Imperial study explicitly limit the scope of analysis to narrowly tailored questions framed within the dominant social order. By design, they fail to capture the broader market forces driving outbreaks and the political decisions underlying interventions."

We can bring in this passage from Wallace (2020: 27) in which he sarcastically comments on an expert from Australia: "In a commentary on the new coronavirus, one Simon Reid, a professor of communicable disease control at the University of Queensland, instantiates the resulting incoherence.

"Reid pings from topic to topic, failing to weave a whole out of his technicist observations. Such folly isn't necessarily a matter of incompetence or malicious intent on Reid's part. It is more a matter of the contradictory obligations of the neoliberal university."

It is worth noting the operative phrase "technicist observations".

\section{The European Union and the pharmaceutical companies like AstraZeneca}

The vaccination plans of many European countries have been severely interrupted due to the shortage of vaccine doses. The European Medicines Agency has authorized the Oxford/AstraZeneca COVID-19 vaccine for use in all adult age groups after days of doubt. This is the third COVID-19 vaccine given the green light by the EMA, after the ones made by Pfizer and Moderna. Both were authorized for all adults. A month after it received approval in the UK, the EU's regulator declared the Pfizer vaccine safe for general use across the 27 member states.

And criticism of the EU's slow vaccine rollout has been building, not least in Germany where media and politicians have attacked Merkel and her ally the European Commission president, Ursula von der Leyen, in this election year in Germany. The Commission has come in for much criticism in its procurement of vaccines. According to The Guardian, having had no experience of a public procurement exercise on this scale, the Commission handled negotiations with manufacturers more like the trade talks with which it is more familiar, focusing on price and questions of liability rather than securing a maximum of doses fast. https://www.theguardian.com/world/2021/feb/03/eu-leaders-beginfeel-heat-slow-covid-vaccine-rollout /

On 4 February 2021 EU member states had so far collectively administered at least one dose to just $3 \%$ of the 


\section{(C) Center for Promoting Education and Research (CPER) USA}

www.cpernet.org

population, against $59 \%$ in Israel, $15 \%$ in the UK, and $10 \%$ in the US.

In late January and February 2021, the European Union was involved in a spat with the pharmaceutical companies, especially AstraZeneca. The EU had demanded that AstraZeneca divert some of its supply manufactured in Wales to the EU. AstraZeneca has now agreed to supply 9 million more doses by the end of March, a figure which still represents a 50 percent shortfall on its original commitments of 80 million doses in the first quarter. is i in:

With Pfizer, AstraZeneca, and most recently Moderna all reporting delays to Europe's supply, the EU's hopes now increasingly rest on the vaccine produced by Johnson \& Johnson, which reported clinical trial results of 66 percent efficacy (and 100 percent against hospitalization and death). The J\&J jab holds several advantages for the EU. First, it can be used as a single jab, compared to the double injection regimen of most other coronavirus vaccines. One injection per person would simplify the considerable logistical challenge of rolling out the vaccine.

The poor countries on Europe's periphery are likely to be waiting months longer than the EU for vaccines. That raises two problems. The first is immediate: will it be possible for the EU to maintain the integrity of its internal free-movement zone while the countries bordering it are still far from full immunization?

What can we say about these times from an ecolinguistic perspective? The virus has hastened a process of environmental disintegration that has been underway for many years. And the role that language and discourse play, often by downplaying these processes is discussed in detail by Alexander (2009). Nine months ago Monbiot (2020), in an article entitled 'COVID-19 is nature's wake-up call to complacent civilization', wrote: "We have been living in a bubble, a bubble of false comfort and denial. In the rich nations, we have begun to believe we have transcended the material world."

The economic and social effects around the world have now expanded this to a societal fragmentation that seems set to persist. Most European societies in the form of their political elites are still attempting to 'manage' a chaotic public health situation for which no nation or society was prepared.

For Noam Chomsky humans are organic creatures. And an ecological perspective quite clearly must incorporate this truism. In brief, if we are biological organisms, not angels, much of what we seek to understand might lie beyond our cognitive limits; the mysteries that zoonotic viruses pose may well be a point in mind. As Faulkner states: "Humans are part of Nature. On the one hand, we are animals with material needs and organic form. On the other, our actions impact upon the rest of Nature, sometimes degrading it, sometimes remodeling it, always affecting."
A major element in the remodeling of nature is the spread of agribusiness all over the world.

What this can lead to is commented on by Rob Wallace (2021:34): “As industrial agriculture encroaches into the last wild places of the Earth, it's unleashing dangerous pathogens."

The outbreak of the SARS-CoV-2 virus is connected to the spread of industrial agriculture, as Wallace (2021: 36) notes: "Deforestation and development are increasing the rate and taxonomic scope of pathogen spillover from wildlife to food animals and the laborers who tend them. Covid-19 represents only one of a series of novel pathogen strains to have suddenly emerged or re-emerged in the 21 st century as threats to humanity."

The consequences of the global neoliberal capitalist globalization are very evident in Wallace's (2021:37) analysis: "With the wild-foods and agricultural production lines increasing in extent and speed, many a SARS-like coronavirus that successfully spilled over into a food animal or a human could now make its way in short order across the peri-urban landscape to regional capitals such as Wuhan before hopping on the global travel network."

A holistic, ecological, and dialectical perspective on life and the world is required to grasp the complexities of the current pandemic. Just consider the biological complications the writer and biologist Merlin Sheldrake outlines in his book Entangled Life: How Fungi Make Our Worlds, Change Our Minds, and Shape Our Futures. The contrast with a reductionist approach to life forms seems to be the main gist of the book. Especially the mention of the microbial ecosystem of the biome brings out the need to take an all-embracing view and not view things as individual elements. Sheldrake is fascinated by the relationships that arise between humans and more-than-human organisms.

He argues that we are gradually becoming aware of how all living things are dependent on microbes. All humans possess a microbiome consisting of bacteria, with smaller bacteria on them in which viruses live, and which carry still smaller viruses. So humans consist of millions of organisms that work together, cooperate, compete and fight one another.

Actions and attempts to counteract the hegemonic control

There is/was waning confidence in governments' competency in handling the virus and even the ability to roll out vaccinations on schedule. Corona's discourse is all about politics in February 2021. There are plenty of criticisms of and dissatisfaction with government measures in many countries. See the examples further down.

The continuing lockdowns in many European countries scheduled to last until 15th February are leading to increased opposition on the part of many people, as schools remain closed and home office working is required. There is the case of the differentiated policies and types of lockdown in 


\section{(C) Center for Promoting Education and Research (CPER) USA}

wwW.cpernet.org

the sixteen states of Germany. In the German state of Bavaria, there is even a curfew from $9 \mathrm{pm}$ until $6 \mathrm{am}$. In the Netherlands, a curfew from 9 till 4.30 am was announced on 23rd January. There were then large organized protest meetings in several cities, including a riot in Eindhoven, where large groups of young people threw rocks at the police and shot fireworks at them, setting cars on fire and vandalized the railway station. All this can be seen as an indicator of the sociological phenomenon of 'anomie', as the sociological Durkheim termed it.

Rioters set fires in the center of the southern Dutch city of Eindhoven and pelted police with rocks at a banned demonstration against coronavirus lockdown measures, while officers responded with tear gas and water cannons, arresting at least 55 people. Police in the capital of Amsterdam also used a water cannon to disperse an outlawed anti-lockdown demonstration on a major square ringed by museums. Videos showed police spraying people grouped against a wall of the Van Gogh Museum.

On 30 January 2021 police were using water cannon to disperse large crowds of demonstrators who had gathered to protest against what they saw as inadequate government actions and in particular against the daily 12-hour daily curfew the government had authorized.

Seeing the ways, the pandemic has lasted now for a year and how the medicalized and other language has taken over the political order and led to lockdowns around Europe (the UK, Germany, etc.), it is not surprising that many people are reacting against this hegemonic control that takes the form of political control.

We can mention the opinion polls in Germany that show that now $57 \%$ of the people are dissatisfied with the way the Government is managing the pandemic situation. In Germany, you could hear people on a phone-in program who are very dissatisfied with the government's long-lasting lockdown and bad management of the vaccination program, which they had announced a few weeks ago. The people who rang up are expecting that more vaccine doses will be supplied so that older and vulnerable patients can be inoculated.

The German government has pledged to offer everyone a vaccine by late September. In addition to frustration with manufacturers, fingers have been pointed at the EU itself, which ordered the vaccines. It is Germany's federal government, which distributes them to state authorities; and state governments, which are in charge of the actual vaccinations. For many Germans, this seeming confusion enhanced the dissatisfaction with the politicians who appear to TV viewers to be arguing among themselves.

"We could carry on like last week council leaders criticize governors and state ministers, state ministers criticize federal ministers and the federal government, the federal government criticizes the European Commission and all criticize the manufacturers," Health Minister Jens Spahn, himself a frequent target of criticism, told ZDF television one day in February. He continued: "The virus is the enemy, the opponent, and no one else," he said. "We all have the responsibility and we are responsible above all for doing better."

Germany is in its second lockdown, which was currently due to expire on February 14. Infection figures are falling, but are still well above the government's target. Germany has seen over 57,100 confirmed deaths in the pandemic. The reductions in contacts are having an impact, but the new variants of the coronavirus are currently spreading rapidly. The Chancellor and the Heads of Government of the Länder have thus decided to extend the contact restrictions currently in place until 7 March. The next few weeks will be "crucially important", said Chancellor Angela Merkel.

In other European countries protest demonstrations are also persisting. In October 2020 anti-lockdown protesters in Paris marched against the new COVID-19 measures adopted by the government and caused considerable damage to public property.

On 31 January 10,000 people demonstrated and protested against the lockdown in Vienna. The police estimated the crowd to be 5,000 strong. The Minister for the Interior forbade the demonstration that the FPÖ party had announced. Thousands of protesters faced off with rows of police in riot gear and facemasks in Vienna at the site of a banned far-right demonstration against Austria's coronavirus restrictions. The affiliation of protesters was unclear, but some expressed support for the Freedom Party.

Vienna police banned numerous protests planned for this weekend, including one by the far-right Freedom Party on Sunday, because protesters have generally failed to observe rules on social distancing and often not worn facemasks. Freedom Party deputy leader Herbert Kickl accused the conservative-led Government of banning criticism in general.

He urged his supporters to go on a walk in the capital instead of attending the banned protest, and to "articulate their displeasure peacefully". Many, often without masks but carrying Austrian flags, opposed conservative Chancellor Sebastian Kurz, chanting and waving banners saying, "Kurz must go". The police prevented the crowd from marching down the ring road.

After riots in the Netherlands set off by the introduction of a nighttime curfew, Austrian police avoided escalation despite having ordered the crowd to disperse, and the atmosphere was tense but peaceful. Police did not confirm how many arrests were made.

In February 2021 Austria loosened the lockdown. We can quote the translations of the measures in effect from the government website.

"Hotels are closed to leisure travelers/tourists. 


\section{(C) Center for Promoting Education and Research (CPER) USA}

www.cpernet.org

Restaurants and bars can only offer takeout/delivery services. Dining in is not permitted. FFP2 masks are required law when picking up food.

A landing ban for flights from the UK, South Africa, and Brazil is in effect.

Entry regulations are in effect.

Shops, museums, libraries, and zoos are open. All shoppers and visitors must wear FFP2 masks.

All other culture and leisure facilities such as theatres, cinemas, gyms, pools, and amusement parks are closed.

Events such as concerts, plays, etc. are canceled.

Hairdressers and similar service providers have been allowed to reopen; negative COVID-19 tests are required for customers.

Cable cars and ski areas have been allowed to reopen. Hotels and restaurants are however still closed and entry regulations (quarantine requirement - see below) are in effect. De facto, skiing is only possible for locals.

A stay-at-home order is in effect from 8 p.m. to 6 a.m.

You are required to keep a minimum distance of $2 \mathrm{~m}(6.5$ ft.) to people from other households.

FFP2 masks are required on public transport and in other public spaces.

In mid-February, the situation will be evaluated further to decide whether more restrictions will be eased.

We will provide more information as it becomes available."

This government information can be seen to encapsulate key elements of the coronavirus discourse: 'Hotels are closed', 'FFP2 masks are required', 'All shoppers and visitors must wear FFP2 masks', 'negative COVID-19 tests are required for customers', 'You are required to keep a minimum distance of $2 \mathrm{~m}$ ', 'A stay-at-home order is in effect' etc.

There are plenty of stories in the UK media about how British people are trying to get around following the lockdown rules. The BBC has reported how some people are responding to the lockdown rules. "Liv has ... been breaking some of the lockdown rules. Despite guidelines banning household mixing indoors, the 28-year-old visits her parents and her two nieces every week. She says she does so to help her mental health."

ITV News reported in January how a wedding attended by around 150 people at a north London school was broken up by police, with the organizer now facing a $£ 10,000$ fine. Initial calls suggested some 400 people had attended the wedding, it is now believed to be 150 . Around 150 people had gathered inside the building for a wedding in breach of COVID-19 regulations, the Metropolitan Police said. The windows of the School in Egerton Road, Stamford Hill, had been covered to stop people from seeing in when police arrived. Many of the guests fled as officers arrived at the Orthodox Jewish school but the force said the organizer will be reported for consideration of a $£ 10,000$ fine, while five others were handed $£ 200$ fixed-penalty notices. Source: https://www.itv.com/news/2021-01-22/covid-wedding-with-400- guests-discovered-at-north-london-school-in-unacceptable-breach-of-

A police spokesperson said: "This was a completely unacceptable breach of the law, which is very clearly in place to save lives and protect the NHS." "This is a deadly and very dangerous disease. We can all see that and we must act responsibly. ...

People across the country are making sacrifices by canceling or postponing weddings and other celebrations and there is no excuse for this type of behavior....

We will not hesitate to take enforcement action if that is required to keep people safe."

A statement from the school, whose principal, Rabbi Avrahom Pinter, died in April after contracting coronavirus, said the hall had been leased to an outside organization and "we had no knowledge that the wedding was taking place".

But Hackney mayor Philip Glanville told BBC news the venue had previously been used for similar events during the pandemic.

"It's a deeply disturbing incident at a time when in Hackney we have seen the largest number of deaths reported since last April," he said.

Under current lockdown rules, weddings and civil partnerships can only take place with up to six people.

Government guidance states they should only go ahead in exceptional circumstances, such as where one partner is seriously ill.

Elsewhere, the Met said the owner of a makeshift nail salon operating from a garden outbuilding in Croydon, south London, is facing a $£ 1,000$ fine, while two women found having treatments there on Monday could get $£ 200$ fixedpenalty notices.

Police have fined seven people who had gathered to watch television and eat together at a home in Romford, east London. The latest examples of people flouting COVID-19 regulations came as police forces and the Government moved to crack down further on illegal gatherings. Home Secretary Priti Patel announced at a press conference in January that fines of $£ 800$ would be handed to people caught at house parties of more than 15 people, doubling after each offense up to a maximum of $£ 6,400$ for repeat offenders.

She said: "The science is clear: such irresponsible behavior poses a significant threat to public health.

"Not only to those in attendance but to our wonderful police officers who attend these events to shut them down.

"As this latest measure demonstrates, we will not stand by while a small number of individuals put others at risk."

In a later press conference, Johnson said in answer to SkyNews correspondent Sam Coates, "We are enforcing the law very stringently with increasing toughness. You'll have seen what Priti had to say about fines. We will do it. We will enforce the law. We will make sure that people don't engage in activities that would mean mass transmission of the disease or 
substantial transmission of the disease. But it depends on all of us. It depends on everybody watching, doing the right thing, avoiding transmission. That is far more powerful and far more effective in stopping the transmission of this virus than police action or new laws from the government. And that's what it takes. The rules are very, very clear, stay at home unless you have a very, very good reason for not staying at home, protect the NHS, and save lives. I think the people of this country understand that. All the evidence is that they comply with the measures when it's necessary and we'll get it done. As I said, they're all signs that this is working, but it's going to need continued resolve and a determination."

\section{Environmental disintegration, COVID-19: The role of the horseshoe crab}

In the context of vaccine production and what the pharmacological multis are engaged in, we need to be clear about what is going on. The consequences for the environment and nature should be put into context.

As Pavid (2020) puts it, the world is rushing to find a safe vaccine to fight COVID-19, the viral lung disease which has swept the planet. More than 100 different vaccines are being tested in the hope that one will work. The successful jabs will have to be carefully checked before they are rolled out. The safety of any new coronavirus vaccine may depend on help from an ancient marine creature. In many parts of the world, researchers will be relying on horseshoe crab blood in these important tests. And since we'll want to vaccinate millions of people in a short space of time, horseshoe crabs could play a big part. Pharmaceutical companies harvest the blood and then return the crabs to the water. Horseshoe crab blood is harvested to produce Limulus amebocyte lysate, LAL.

"Without LAL, you're not going to be able to produce the billions of inoculations that are going to have to come about to handle this pandemic", said John Tanacredi, the director of the Environmental Research and Coastal Oceans Monitoring lab at Molloy College. Horseshoe crabs are like living dinosaurs; they have been on Earth for 445 million years. But now, their future is in question. Living alongside humans can be difficult for horseshoe crabs. They are often used as fishing bait. In Asia, they are also harmed by pollution, rising sea levels, and building work. Some die after being bled for medical testing, although we don't know how many. Plus, lots die because they strand upside down on beaches after coming to land to mate."

A group of horseshoe crabs gathers together to spawn. Image (C) Justin Warner via Flickr, licensed under CC BY-SA 2.0.

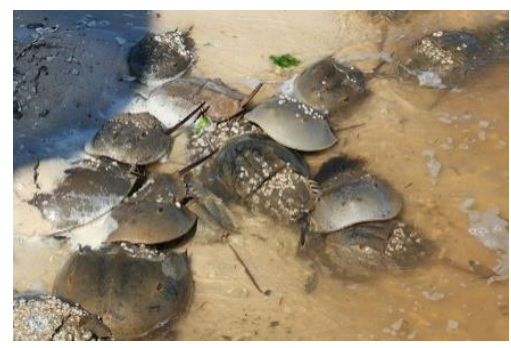

Here's how drug developer Charles River, one of five bacteria and other contaminants at less than one part per companies licensed by the FDA to produce and sell LAL, trillion without killing the creatures. harvests crabs and turns their blood into tests that can detect

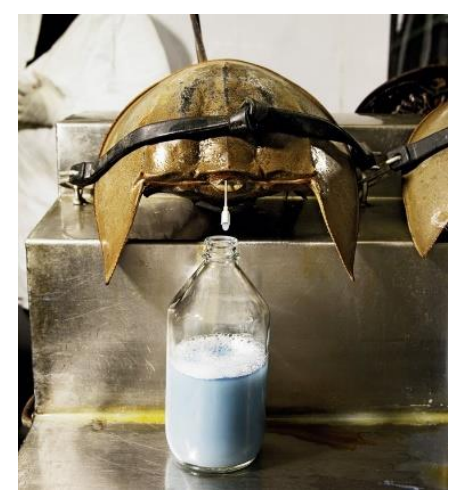

Wallace (2020: 101) discusses how horseshoe crab blood is harvested to produce Limulus amebocyte lysate, LAL, a vital detecting system for bacterial contamination and concludes: "Capitalism is not just about producing metabolic rifts between our economies and ecologies along the way to profits, destroying our capacity to socially reproduce as civilization. It's also about producing new ecologies that reproduce capital alienating the web of life. From working people to creatures as old and odd as the dinosaurs."

Let Wallace provide a conclusion to the scope of the ongoing pandemic discourse: "SARS-CoV-2, the coronavirus behind COVID-19, is on the march. It's infecting hundreds of 


\section{(C) Center for Promoting Education and Research (CPER) USA}

www.cpernet.org

thousands of people a day the world over. In countries that With little scientific backing, politicians such as Donald handled the outbreak badly among them the US, Britain, and Trump have declared that a mythical herd immunity leaving Brazil government rhetoric has at times suggested, in the early perhaps millions dead in its wake will save us." days and pre-vaccine, letting the virus largely 'run its course'.

\section{References}

Abbasi, Kamran (2021) 'COVID-19: Social murder, they wrote - elected, unaccountable, and unrepentant', British Medical Journal 04 February 2021. [https://www.bmj.com/content/372/bmj.n314.full]

Alexander, Richard J. (2009) Framing Discourse on the Environment. A Critical Discourse Approach. New York: Routledge. Alexander Richard J. (2020) 'An ecolinguistic perspective on the discourse of the Corona Virus', Ecolinguistica: Revista brasileira de ecologia e linguagem (ECO-REBEL): v.6 n.4 (2020)

[https://periodicos.unb.br/index.php/erbel/article/view/35672/28323]

Allnutt, Chris (2021) 'An Education in Dissent', The Financial Times 12 February 2021

[https://www.ft.com/content/3ab48f92-f779-4f77-b39a-8fae7ff9f452] (accessed 19 February, 2021)

Bamford, Connor (2021) 'One year since we first reported on this coronavirus - what we've learned, and still need to know',

The Conversation January 14, 2021. [https://theconversation.com/one-year-since-we-first-reported-on-this-coronaviruswhat-weve-learned-and-still-need-to-know-152762]

Chesler, Caren (2016) 'Medical Labs May Be Killing Horseshoe Crabs. Drawing the crabs' blue blood for vital medical testing can condemn the animals to die, even after they are returned to the sea', Scientific American June 9, 2016.

Dreger, Holly (n.d.) 'Pandemic Principles: Responding to Anomie During Unprecedented Times'.

[https://www.socialworker.com/feature-articles/practice/pandemic-principles-anomie-unprecedented-times]

Durkheim, Émile (1897) Le Suicide: Étude de sociologie. Paris.

Faulkner, Neil (2021) 'Covid, climate, and "dual metabolic rupture", The Ecologist

[https://theecologist.org/2021/feb/01/covid-climate-and-dual-metabolic-rupture] (accessed 17 February, 2021)

Foster, J. B. (2020) 'EVERYTHING AFFECTS AND IS AFFECTED BY EVERY OTHER THING', ROAR Roundtable:

COVID-19 and the Climate Crisis, June 25, 2020 [www.resilience.org/stories/2020-06-25/roar-roundtable]

Gelfand, Alexander (2020) 'COVID-19's Lasting Toll on Mental Health', Hopkins Bloomberg Public Health Magazine. Fall 2020. [https://magazine.jhsph.edu/2020/COVID-19s-lasting-toll-mental-health](accessed 18 February, 2021)

Gramsci, Antonio (1971) Selections from the Prison Notebooks (ed. and translated by Hoare, Q. and Nowell Smith, G.). London: Lawrence \& Wishart.

Monbiot, George (2020) 'COVID-19 is nature's wake-up call to complacent civilisation', The Guardian Mar 252020.

Monbiot, George (2021) 'What's as scary as Covid? The fact our leaders still have no plan to control it', The Guardian Jan 132021.

Pavid, Katie (2020) 'OUR BROKEN PLANET. Horseshoe crab blood: the miracle vaccine ingredient that's saved millions of live', Natural History Museum, 3 December 2020, Last updated 15 January 2021

[https://www.nhm.ac.uk/discover/horseshoe-crab-blood-miracle-vaccine-ingredient.html]

(Accessed 13 February, 2021.)

Sahakian, Barbara Jaquelyn et al. (2021) 'How the pandemic may damage children's social intelligence', The Conversation January 14, 2021. [https://theconversation.com/how-the-pandemic-may-damage-childrens-social-intelligence-154975]

Sheldrake, Merlin (2020) Entangled Life: How Fungi Make Our Worlds, Change Our Minds, and Shape Our Futures. London: The Bodley Head.

Smith K. F. et al. (2014) 'Global rise in human infectious disease outbreaks', Journal of the Royal Society 11 (101): 20140950. (Accessed 15 February, 2021.)

Wallace, Rob (2020) Dead Epidemiologists. On the Origins of COVID-19. New York: Monthly Review Press.

Wallace, Rob (2021) 'Planet Farm', New Internationalist January-February 2021, pp. 34-37.

Whitaker, Phil (2021) 'Notes on a crisis: Why we must not allow death on this scale to be neutralised or normalised', New Statesman 29 Jan - 4 Feb. [https://www.newstatesman.com/politics/health/2021/01/notes-crisis-why-we-must-not-allow-deathscale-be-neutralised-or-normalised] 